\title{
Compound Open Depressed Displaced Frontal Bone and Supraorbital Rim Fracture and Its Associated Injury: A Case Report
}

\author{
Ingrid A Widjaya, Bilzardy F Zulkifli, Muhammad Z Arifin \\ Department of Neurosurgery \\ Faculty of MedicinePadjadjaran University-Dr. Hasan Sadikin General Hospital \\ Jl. Pasteur No.38 Bandung \\ Email: ingridwidjaya@gmail.com
}

\begin{abstract}
Compound open depressed displaced frontal bone and supraorbital rim fracture was an uncommon variant of skull fractures and present a management challenge due to their anatomy and potential associated injuries, including intracerebral hematoma, extraocular muscle injury, and traumatic optic neuropathy. We presented a case of 22 years old male with multiple trauma including moderate head injury presented to our emergency unit with a decrease of consciousness and seizures. The initial GCS was E3M6V4 (13/15). Head CT Scan demonstrated a displaced depressed fracture at left frontotemporal with adjacent intracerebral hemorrhage and cerebral prolapse. The patient underwent an emergency surgery. The fragmented bones were removed, we left the prolapse untouched, followed by duraplasty using a pericranial flap, and we fixed the fragmented supraorbital rim. Within 24 hours follow up, the patient already gains a full consciousness (GCS 15/15). The patient discharged after 3 days hospitalization with stable neurological condition. We concluded proper emergency surgery, removal of bone fragments and fixation on the superior orbital rim contributed to an optimal outcome.
\end{abstract}

Keywords: open depressed fractures, supraorbital rim, frontal bone 


\title{
Fraktur Depresi Tulang Frontal Terbuka dengan Pergeseran dan Fraktur Rima Supraorbita serta Cedera yang Berkaitan: Sebuah Laporan Kasus
}

\author{
Ingrid A Widjaya, Bilzardy F Zulkifli, Muhammad Z Arifin
}

\author{
Departemen Bedah Saraf \\ Fakultas Kedokteran Universitas Padjadjaran / RSUP. Dr. Hasan Sadikin Bandung \\ Jl. Pasteur 38, Bandung 40161, Indonesia \\ Email: ingridwidjaya@gmail.com
}

\begin{abstract}
Abstrak
Fraktur depresi tulang frontal terbuka dengan pergeseran dan fraktur rima supraorbita merupakan varian fraktur kranium yang jarang terjadi dan memiliki tantangan dalam manajemen akibat lokasi anatominya dan potensi cedera yang berkaitan, termasuk hematoma intraserebral, cedera otot ekstraokular, dan neuropati optic traumatik. Kami menyajikan kasus seorang pria berusia 22 tahun dengan trauma multipel yang meliputi cedera kepala sedang. Pasien datang ke unit gawat darurat dengan penurunan kesadaran dan kejang. GCS awal adalah E3M6V4 (13/15). CT scan kepala menunjukkan fraktur depresi pada frontotemporal kiri dengan pergeseran dan perdarahan intraserebral yang berdekatan serta prolaps serebral. Pasien menjalani pembedahan emergensi. Tulang yang terfragmentasi diangkat, dilanjutkan dengan duraplasti menggunakan flap perikranial, dan kami memperbaiki rima supraorbita yang terfragmentasi. Dalam 24 jam follow-up, pasien sadar penuh (GCS 15/15). Pasien dipulangkan dari rumah sakit setelah 3 hari perawatan dengan kondisi neurologis stabil. Pembedahan emergensi yang tepat, pengangkatan fragmen tulang dan fiksasi pada rima orbita superior memberikan hasil yang baik.
\end{abstract}

Kata kunci: fraktur depresi terbuka, rima supraorbita, tulang frontal 


\section{Case Report}

\section{Introduction}

A depressed skull fracture is a result of impact force distribution over a relatively small area. Fragments of bone may separate from the cranium and driven inwards to a depth equivalent to or more than the thickness of the skull. The underlying duramater may either remain intact or be lacerated, and the underlying brain may be contused. A depressed skull fracture can cause compression of adjacent structures. ${ }^{1}$ The supraorbital rim is the strongest part of the frontal bone and provides an outlining structure to the orbit. If it is displaced, the patient should be assessed functionally for consideration of fixation. ${ }^{2}$

In general, the principle of management of compound depressed fractures is debridement and elevation, with the elevated bone fragments being replaced into position after proper closure of the duramater. The presence of orbital roof fractures are a challenge to manage due to their concomitant trauma and the risks to trauma of the eye and extraocular muscles. ${ }^{1,2}$

\section{Case}

A 22-year-old man suffered a blunt force head trauma, caused by a motor vehicle accident 7 hours prior to admission and there was a history of seizure and vomiting after accident. The patient's consciousness decreased with Glasgow Coma Scale scored E3M6V4 $(13 / 15)$ on admission. We found a lacerated wound located at left frontotemporal region; sized $2 \times 3 \times 1 \mathrm{~cm}$ based on bone fracture, with LCS leakage from the wound (Figure 1). Clinical examination revealed swelling over the left side of the face with restricted mouth opening, periorbital ecchymosis and subconjunctival hemorrhage. Visual acuity and eyeball movement could not be examined on admission. We also found same size on both pupils' diameter but consensual light reflex on left eye is stronger than the direct. Initial fundoscopy showed no papilledema.

He sustained multiple traumas including moderate head injury, open depressed fracture with cerebral prolapse, closed fracture of the left zygomatico maxillary complex. Left traumatic optical neuropathy was suspected on admission. 
Case Report

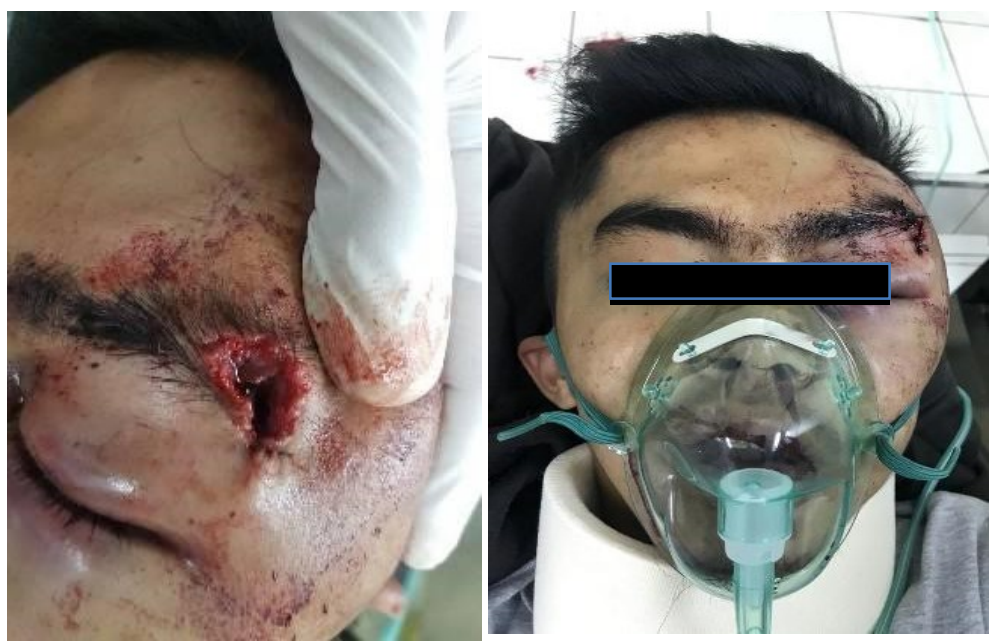

Figure 1 Clinical presentation of lacerated wound at left frontotemporal, $2 \times 3 \times 1 \mathrm{~cm}$ based on bone fracture

An emergency hemorrhage-control scalp stitches were done in nearby emergency facilities. We performed head CT-Scan and found a depressed skull fracture at left frontotemporal with an intracerebral hemorrhage deep below to the fracture (Figure 2). The 3D skull reconstruction was performed to get a more detailed information about the fracture (Figure $3)$.

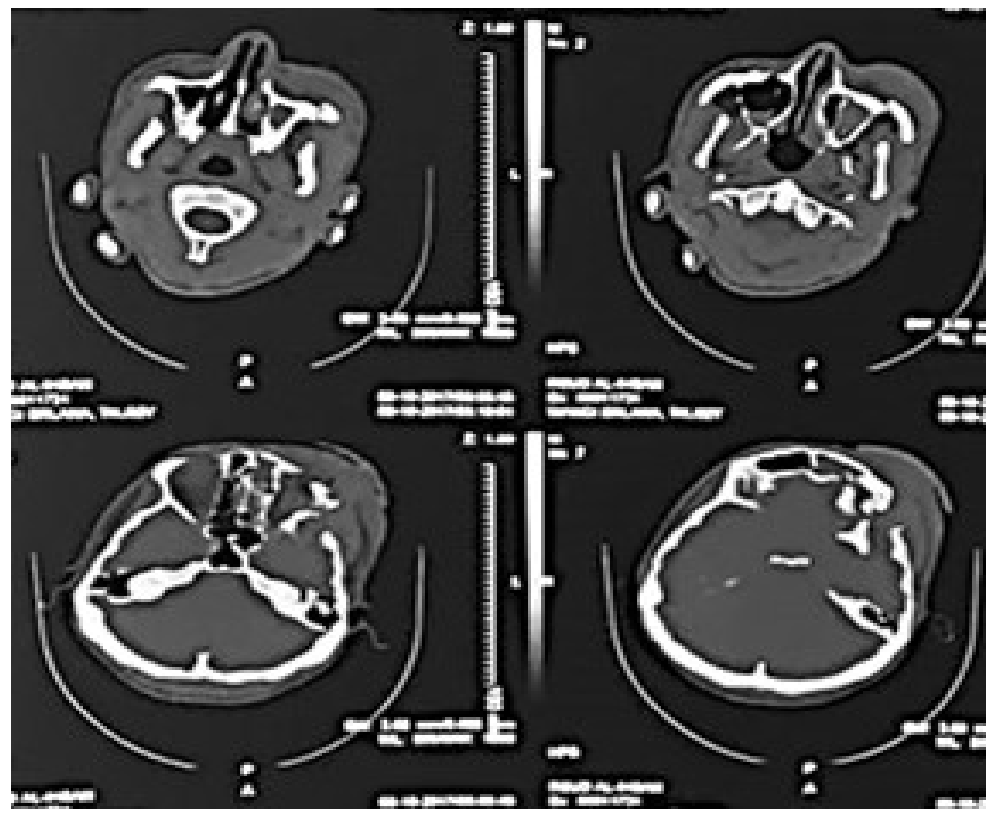




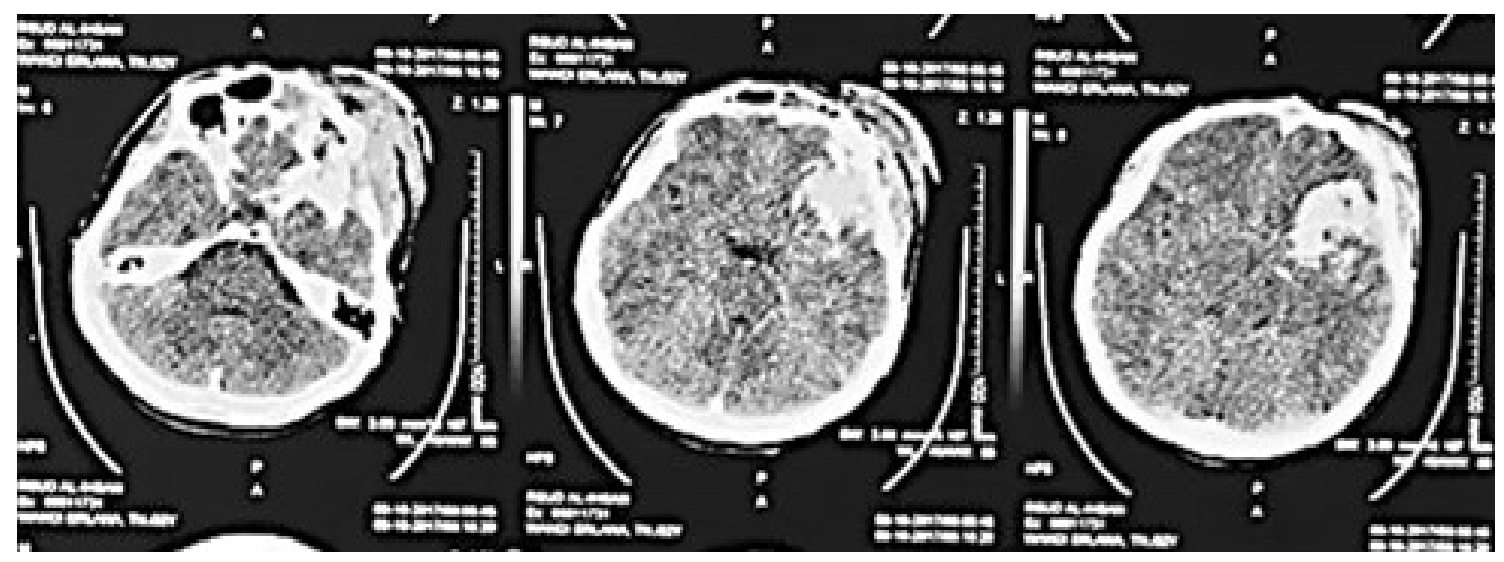

Figure 2 Radiographic examination revealed multiple fractures of the frontal, maxillary and infraorbital processes of zygoma and left zygomatic arch and a hyperdense mass $4.2 \mathrm{~cm} \times 3.1 \mathrm{~cm} \times 1.2 \mathrm{~cm}$ at left frontal, adjacent to depressed skull fracture
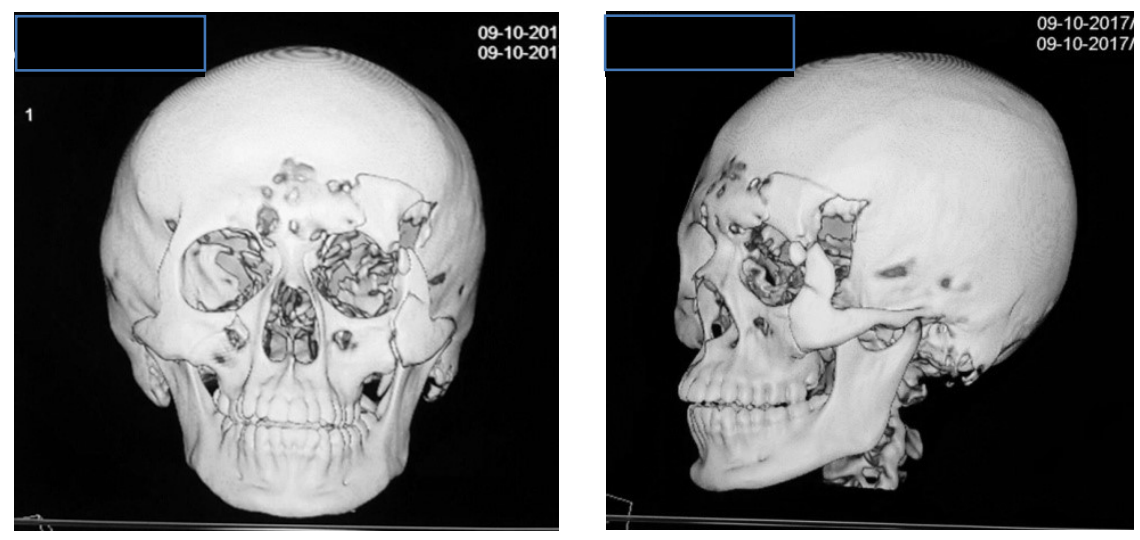

Figure 3 The 3D reconstruction shows depressed and displaced left frontal bone fracture, left superior orbital rim fracture and left zygomaticomaxillary fracture

We performed an emergency craniectomy procedure, debridement, and hematoma evacuation by performing half coronal incision. Layer-wise dissection was done to expose the fracture line. During operation we found depressed fracture, displaced, fragmented, interlocking $5 \mathrm{~cm} \times 3 \mathrm{~cm}$ fractures of left lateral superior orbital rim and fracture of left frontal sinus laminas. The fracture fragment sticks at orbital roof and causing superior oblique and superior levator palpebrae muscle incarceration.

We also found cerebral prolapse and intracerebral hematoma in the underneath the fracture (about $10 \mathrm{cc}$ in volume), the inward force of the depressed skull fragment caused a 


\section{Case Report}

dural laceration (about $4 \mathrm{~cm}$ wide) and caused the brain tissue of the right superior frontal to prolapse through (Figure 4).

After removing the prolapsed tissue, intracerebral hematomas, and the bone fragment, a duraplasty was done using a pericranial flap, the prolapsed brain tissue remains untouched. Three titanium miniplates was used to fix the fragmented superior orbital rim and frontozygomatic fracture, screwed by $5 \mathrm{~mm}$ mini screws and the scalp was sutured. We also performed broad antibiotic therapy for infection prevention and steroid administration as management for his optic neuropathy. Within 24 hours follow up, the patient already gained a full consciousness (GCS 15), no alteration in visual acuity, although eyeball movement was not able to be evaluated due to post-operative swelling. The patient was discharged after 3 days of care with good condition. On his one week visit after discharge, he had good visual acuity on both eyes, no alteration in eyeball movement, and planned to have elective reconstructive surgery for his zygomaticomaxillary complex fracture.
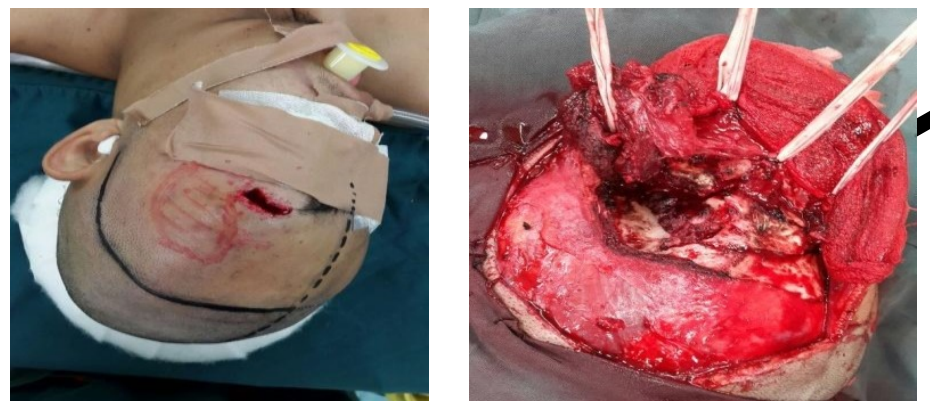

Bone fractures segments at orbital roof caused incarceration of the superior oblique and superior levator palpebrae muscle
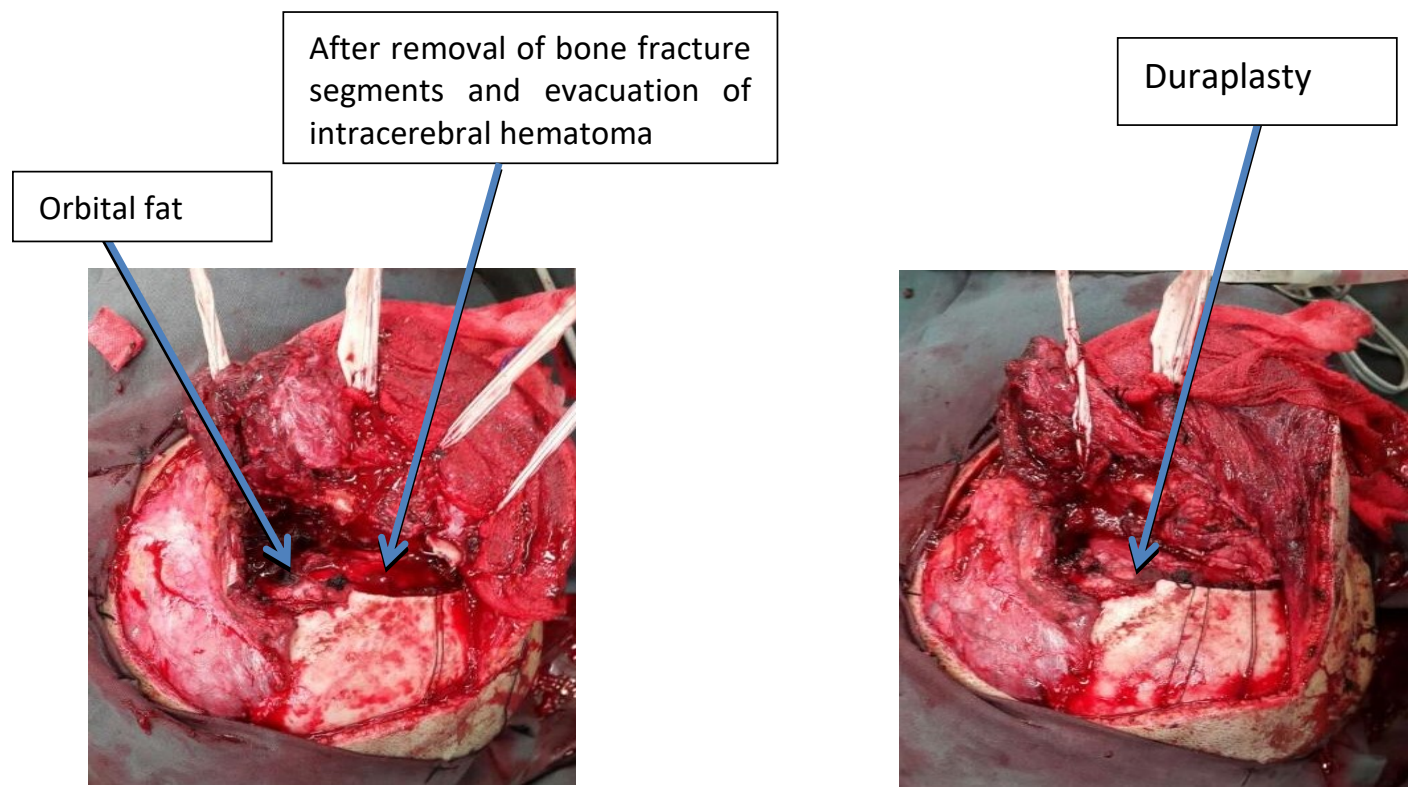
Case Report

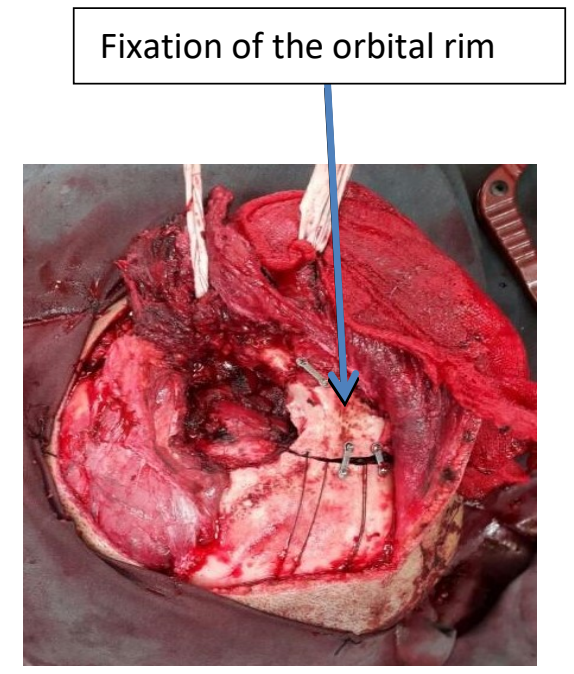

Figure 4 Intraoperative findings at left frontotemporal; found depressed fracture, fragmented, interlocking, $5 \mathrm{~cm} \times 3 \mathrm{~cm}$, displaced fracture of left lateral superior orbital rim and fracture of left frontal sinus laminas with cerebral prolapse. After removal of fracture segment and intracerebral hematoma, a pericranial flap was performed, and superior orbital rim was fixated with plates and screws.

\section{Discussion}

An open compound depressed skull fractures is a neurosurgical emergency due to the dural laceration and the injury beneath the fracture that affect the manifestation of neurological deficit. Brain injury following open depressed skull fracture is a very common complication. In Salia et. al. study, dural tear is a complication in $55.5 \%$ of patients with depressed skull fractures. Preoperatively, the presence of dural tear can be predicted with the depth of fracture (odds ratio 1.3, $\mathrm{p}<0.001$ ), the presence of pneumocephalus (odds ratio 2.8, $\mathrm{p}=0.005$ ), and brain contusions/intracerebral hematoma (odds ratio 5.5, $\mathrm{p}<0.001$ ). ${ }^{3}$ In Rolekar study, the frontal region was the most common site of injury in $52 \%$ patients. ${ }^{4}$ In Afzal et al. study, frontal region was the most common site of injury in $55.6 \%$ patients followed by occipital in $16.7 \%$, parietal in $15.6 \%$ and temporal in $12.2 \%$ cases. ${ }^{5}$ Depressed skull fractures are often associated with underlying hematoma, contusion, and venous sinus involvements which might be much dangerous for patients as compared to fracture alone. In Mehdi etal. study, 31 patients had brain contusion and four had subdural hematoma beneath the fracture. ${ }^{6}$ In Afzal et al. study, $35(38.8 \%)$ patients had brain contusions; $10(11.2 \%)$ patients had extradural hematoma and 


\section{Case Report}

five $(5.6 \%)$ patients had subdural hematoma and five (5.6\%) patients had involvements of venous sinuses. ${ }^{5}$

Orbital roof fractures following compound depress skull fractures are relatively uncommon, with single institution estimates ranging from 1 to $9 \%$ of facial fractures. ${ }^{7}$ Because frontal and paranasal sinuses prevent direct transmission of forces from the superior orbital rim to the orbital roof, orbital roof fractures tend to occur with high-energy mechanisms and are typically accompanied by injuries to surrounding structures. ${ }^{7.8}$ In particular, there may be significant ophthalmologic and neurologic injuries, including brain injury with or without cerebrospinal fluid (CSF) leak, brain herniation, globe rupture, optic neuropathy, retrobulbar hematoma, strabismus due to extraocular muscle entrapment, pulsatile exophthalmos, and delayed encephalocele. ${ }^{9}$

Crucial information for the diagnosis and management of a patient with suspected extraocular muscle injury can be obtained through CT scan or an MRI. The gold standard imaging workup for suspected orbital wall fractures, consists of high resolution CT scans (facial or orbital thin slices of 1-2 $\mathrm{mm}$ ), since it provides the best image of the relation between the muscle and the fracture site. The MRI even provides a better image of the structural situation of the muscle and soft tissues.

A number ofstructures that are involved in eye movements may be affected and may result in extraocular muscle entrapment. There are three basic mechanisms that can affect the extraocular muscles in the event of trauma: muscle involvement in orbital wall fractures, muscle contusion and traumatic disinsertion or laceration of the extraocular muscles.

Following orbital trauma, traumatic optic neuropathy can also happen, and classified into a direct form (due to penetrating injury to the nerve) and an indirect form (due to transmission of forces to the optic nerve from a distant site). Most indirect traumatic optic neuropathies are posterior to where the central retinal artery enters the nerve and thus are associated with normal retinal circulation. Posterior axonal injury does not cause any acute effects on the optic disc either, so posterior indirect traumatic optic neuropathy can present with a normal funduscopic examination. The only ophthalmic examination findings in posterior indirect traumatic optic neuropathy might be decreased acuity, decreased color vision, possibly field defects, and relative afferent pupillary defect if the injury is unilateral or asymmetric. Since establishing diagnosis of traumatic optic neuropathy is only possible in a conscious patient supported by radiologic finding on orbital CT Scans, we can only estimate its diagnosis on rapid eye examination in trauma patients with decreased consciousness. ${ }^{10}$ 


\section{Case Report}

In our case, the patient came with decrease of consciousness, frontal bone fracture brain herniation with CSF leak, edema, and associated cortical lesions and optic neuropathy which need to have an emergent repair.

We established Advanced Trauma Life Support (ATLS) protocols begin by first addressing life-threatening injuries followed by multidisciplinary assessment by neurosurgeon, craniomaxillofacial surgeons, and ophthalmologists. When the patient is hemodynamically stable, we perform emergency craniectomy debridement and evacuation to remove the bone fragments that stick to the extraocular muscle. We left the prolapsed part untouched to minimize neurological deficits, then the procedure was followed by duraplasty using a pericranial flap. Reconstruction of the orbital roof using titanium and microscrews has been shown to yield the most stable and effective results. ${ }^{11}$ Displaced fractures aretreated via wide exposure of half coronal approach. The goal is reduction of the fracture and rigid fixation in at least two fracture sites for functional consideration. ${ }^{1}$ We treat traumatic optic neuropathy using steroids during three days hospitalization.

\section{Conclusion}

We report a case of compound open depressed displaced frontal bone fracture and cerebral prolapse over supraorbital rim in moderate brain injury presenting with a decrease of consciousness. Determination of the fracture and surrounding injured structures is very important to plan for the best strategy in managing the case. Surgical intervention should be initiated immediately regarding the potential deficits. Proper emergency surgery, removal of bone fragments and fixation on the superior orbital rim contributed to an optimal outcome.

\section{References}

1. Connon VF, Austin JB, Nastri AL. Orbital roof fractures: a clinically based classification and treatment algorithm. Craniomaxillofac Trauma Reconstruction 2015;8:198-204.

2. Reily P. Initial management of head injury. Mc Graw Hill Australia; 2007. p11-5.

3. Salia SM, Mersha HB, Aklilu AT, Baleh AS, Johansen ML Predicting dural tear in compound depressed skull fractures: a prospective multicenter correlational study. World Neurosurgery. 2018; 114:e833-9.

4. Rolekar NG. Prospective study of outcome of depressed skull fracture and its management. Int J Medical Sci Public Health. 2014;3(12):1540-5.

5. Afzal A, Ahmad S, Rehman L, Javeed F. Impact of depressed skull fracture surgery on outcome of head injury patients. Pak J Med Sci. 2018;34(1):130-4.

6. Mehdi SA,Depressed skull fracture: Interrelationship between CT evaluation of \& its clinical findings. Professional Med J. 2010;17:616-22.

7. Cossman JP, Morrison CS, Taylor HO, Salter AB, Klinge PM, Sullivan SR.Traumatic orbital roof fractures: interdisciplinary evaluation and management. Plast Reconstr Surg 2014;133(3):335e-43e.

8. Righi S, Boffano P, Guglielmi V, Rossi P, Martorina M.Diagnosis and imaging of orbital roof fractures: a review of the current literature. Oral Maxillofac Surg 2015;19(1):1-4. 


\section{Case Report}

9. Ha AY, ManghamW, FrommerSA, Choi D, Klinge, P, TaylorHO, SullivanSR. Interdisciplinary management of minimally displaced orbital roof fractures: delayed pulsatile exophthalmos and orbital encephalocele. Craniomaxillofacial trauma \& reconstruction. 2017;10(1):11-5.

10. Ventura RE.The neuro-ophthalmology of head trauma. The Lancet Neurology. 2014;13(10):1006-16.

11. Mokal NJ, Desai NF. Titanium mesh reconstruction of orbital roof fracture with traumatic encephalocele. Craniomaxillofac Trauma Reconstr. 2012;5(1):11-8. 